\section{An index of structural complexity for Apennine beech forests}

\author{
Francesco Maria Sabatini ${ }^{(1)}$, Sabina Burrascano ${ }^{(1)}$, Fabio Lombardi ${ }^{(2)}$, \\ Gherardo Chirici ${ }^{(2)}$, Carlo Blasi ${ }^{(1)}$
}

\begin{abstract}
A broad interest exists in developing structure-based indicators to use as proxies for other attributes that are difficult to assess, such as biological diversity. Summary variables that account for stand-scale forest structural complexity could facilitate the comparison among stands and provide a means of ranking stands in terms of their potential contribution to biodiversity. We developed an index of structural heterogeneity (SHI) for beech forests in southern Italy: (i) we established a preliminary list of 23 structural variables obtained from data routinely collected in forest inventories; (ii) we quantified these variables in a set of 64 beech-dominated stands encompassing a wide range of variability in the Cilento, Vallo di Diano and Alburni National Park; (iii) we identified a core set of attributes that take into account the main sources of structural he terogeneity identified in reference old-growth forests; and (iv) we combined these core attributes into a simple additive index (SHI). We identified eight core attributes that were rescaled to the range 0 to 10 using regression equations based on raw attribute data. The SHI was calculated as the sum of these attribute scores and then expressed as a percentage. The index performance was evaluated against ten reference old-growth beech stands in the Apennines. The index ranged between 38 and 79.1 (median=59.4) and was distributed normally for the calibration dataset. The SHI successfully discriminated between old-growth (range=71.9-99.9, median=85.1) and early-mature to mature forests. Furthermore, the SHI linearly increased with stand age and was higher in multi-layer high forests than in single- and double-layer forests. However, a large variation was detected within both management types and age classes. SHI could be helpful for foresters as a tool for quantifying and comparing structural heterogeneity before and after a silvicultural intervention aimed at restoring the structural complexity in second-growth stands.
\end{abstract}

Keywords: "Cilento, Vallo di Diano and Alburni" National Park, Fagus sylvatica, National Forest Inventories, Old-growth Forests, Structural Heterogeneity Index

\section{Introduction}

The theoretical and practical relevance of the structural attributes of forest stands is being increasingly acknowledged (Franklin et al. 2002, Lindenmayer et al. 2000). Forest structure exerts a strong control upon biological diversity, since some structural components, such as coarse woody debris or cavity trees, provide resources and habitat for a wide range of species belonging to several taxonomic groups, such as birds, bats, insects, mosses, and lichens (Winter \& Moller 2008, Brunialti et al. 2010, Jung et al. 2012).

A broad interest exists in developing structure-based indicators to use as proxies for other attributes that are difficult to assess. Several studies have tried to quantify the diversity of forest structures in a stand through the definition of synthetic indexes. Some of these indexes were designed to rank forest stands on the basis of management intensity (Schall \& Ammer 2013), developmental phases (Whitman \& Hagan 2007) or natural- ness (McRoberts et al. 2012), while others quantify the overall forest structural complexity, also referred to as structural heterogeneity, based on several attributes (Staudhammer \& LeMay 2001, Zenner \& Hibbs 2000 , Houghton 2005).

Stand structural complexity is essentially a measure of the variety and relative abundance of different structural attributes in a given stand. Particular attention is usually paid to those attributes that quantify variation (e.g., standard deviation of tree diameters) because they directly describe habitat heterogeneity at the stand scale (McElhinny et al. 2005, Staudhammer \& LeMay 2001). In forestry, structural heterogeneity is strictly related to the spatial pattern, size distribution and height variability of trees, whether living or dead. However, depending on the objective of the study, other sources of complexity may be taken into account; for instance, vascular flora or litter distribution may still host certain organisms, modulate the resource di-
(1) Department of Environmental Biology, University of Rome "La Sapienza", p.le Aldo Moro 5, I-00185 Rome (Italy); (2) Dipartimento di Bioscienze e Territorio, Università degli Studi del Molise, c.da F.te Lappone snc, I-86090 Pesche (IS, Italy)

(a) Francesco Maria Sabatini (francescomaria.sabatini@uniroma1.it)

Received: Oct 22, 2013 - Accepted: May 21, 2014

Citation: Sabatini FM, Burrascano S, Lombardi F, Chirici G, Blasi C, 2015. An index of structural complexity for Apennine beech forests. iForest 8: 314-323 [online 2014-0903] URL: http://www.sisef.it/iforest/ contents/?id=ifor1160-007

Communicated by: Renzo Motta

stribution and create patchy environmental conditions. Furthermore, structural complexity can be defined at different scales (e.g. plot, stand, forest or landscape scale), and each scale can be assumed to be important for specific categories of organisms, depending on their size, dispersal ability and overall "perception" of the physical environment. A stand-scale index of structural complexity may facilitate the comparison of stands based on their potential contribution to biodiversity (McElhinny et al. 2006, Whitman \& Hagan 2007), since structural heterogeneity is usually assumed to be correlated with different components of plant and animal diversity (Neumann \& Starlinger 2001, Bartels $\&$ Chen 2009, Brunialti et al. 2010, Taboada et al. 2010, Jung et al. 2012). Ideally, an index of structural complexity should be easily applied by forest and land managers, and should use data routinely collected in National Forest Inventories (NFIs) so as to be widely applicable (Chirici et al. 2011, Corona et al. 2011).

Ranking stands according to their structural complexity may be challenging, since even ecologically similar forest stands within the same region may accumulate complexity in different ways (Donato et al. 2012). Structural heterogeneity arises from the occurrence of a number of different attributes whose complex interactions make its quantification an extremely difficult task (Whitman \& Hagan 2007). Furthermore, the relative contribution of each structural attribute to forest complexity may vary consistently across systems. Indeed, different subsets of attributes have been used by different authors for calculating stand structural heterogeneity in different regions and forest types, and all the proposed indexes are context-dependent to some extent (McElhinny et al. 2005). 


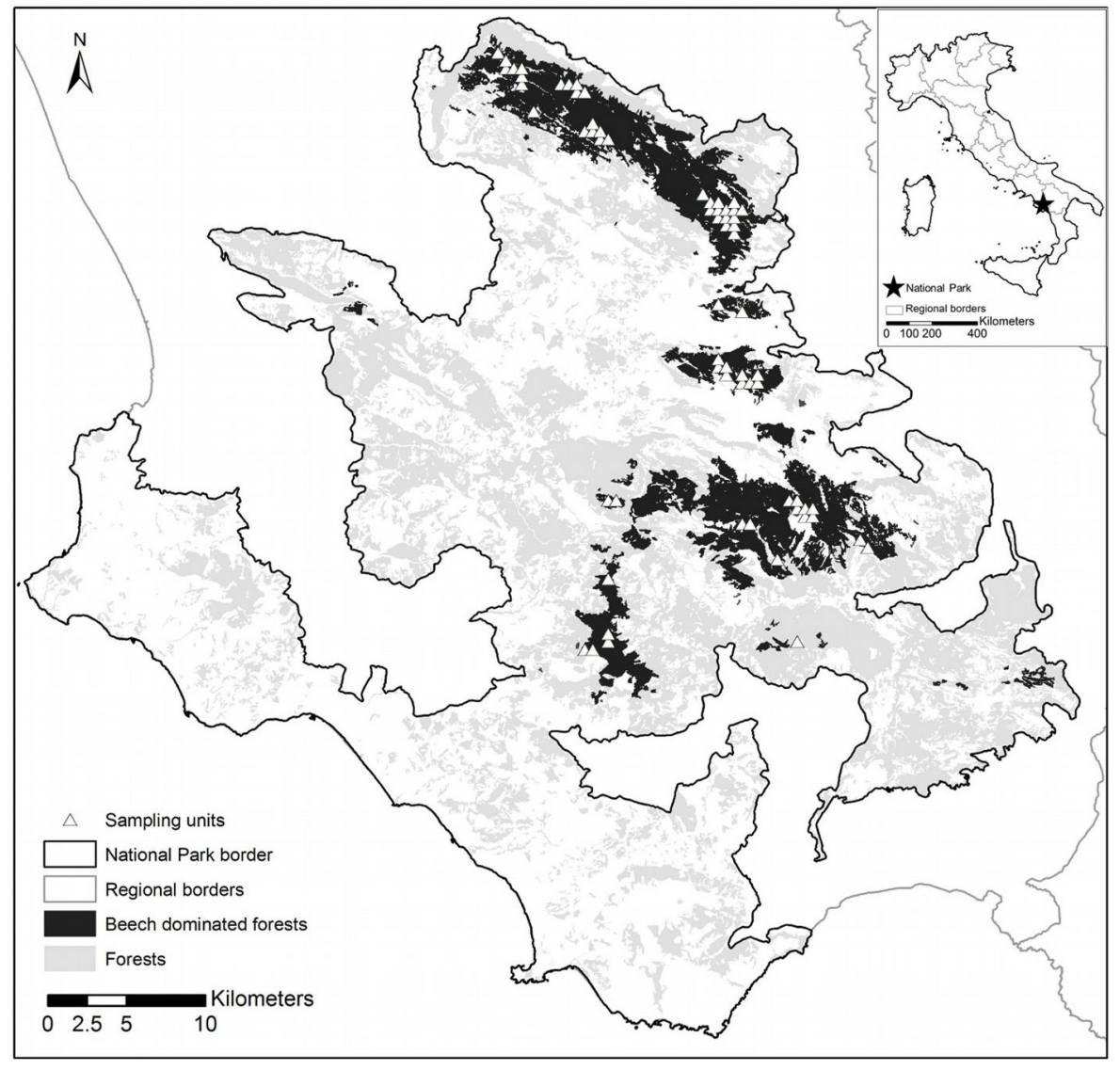

Fig. 1 - Distribution of forests in the Cilento, Vallo di Diano and Alburni National Park. Forests (light gray), beech forests (dark gray) and location of the sampling units within the beech forests (white triangles) are shown.

Recently, McElhinny et al. (2006) proposed an objective and quantitative methodology for constructing an index of structural complexity that identifies key structures to take into account in a specific context. They first established a comprehensive suite of stand structural attributes. These attributes were then measured in a set of stands representing the range of conditions occurring in a given region. From the analysis of these data, they finally identified a core set of attributes that were subsequently combined into a simple additive index, in which attributes were scored according to their overall regional variability (McElhinny et al. 2006).

Here, we applied this methodology to develop a stand-scale index of structural heterogeneity for Apennine beech forests. To identify the suite of attributes to include in this index of structural heterogeneity, we first explicitly defined the main sources of structural complexity commonly reported for beech natural forests in Italy and southern Europe. We considered old-growth condition as the reference state, given that late successional forests, especially old-growth stands, are known to have a high horizontal

\section{Materials and Methods}

\section{Study area and data collection}

Data were collected in forest stands dominated by beech (Fagus sylvatica) in the Cilento, Vallo di Diano and Alburni National Park (hereafter referred to as Cilento $\mathrm{Na}$ tional Park), southern Italy (Fig. 1). We limited our analysis to beech forests since they account for almost $10 \%$ of the Italian forests (more than 1 million ha, Gasparini \& Tabacchi 2011) and encompass $21.7 \%$ of the Cilento National Park. Furthermore, most of the remnant old-growth stands in southern Europe are dominated by beech. This has led to a body of knowledge being accumulated in recent years about the structure and variability of this forest type under natural dynamics (Bianchi et al. 2011, Motta et al. 2011, Travaglini et al. 2012, Rugani et al. 2013, Sabatini et al. 2014).

Sampling units were identified based on an aligned systematic design, overlaying a 500 $\mathrm{m}$ grid on the beech forest distribution map. Plots were selected with the help of the Park planning records and photo-interpretation of digital aerial photographs (Flight IT2000, nominal resolution $1 \mathrm{~m}$ ), with a nominal scale of 1:25.000. We excluded areas whose structural heterogeneity could derive from recent harvesting, i.e., by the creation of stumps and the co-occurrence of remnant trees (or standards) and very young trees. We focused on early-mature to mature forests where structural heterogeneity is likely due to natural forest dynamics (tree senescence and death, establishment of natural regeneration and gap dynamics, etc).

Overall, 64 sampling units across 12 forest areas were selected, encompassing an area of about $137 \mathrm{~km}^{2}$ (Fig. 1). These included stands diversely managed, ranging from coppices with different standard densities, to even- and uneven-aged high forests. Some of the stands showed old-growth features, such as large old trees, logs and snags.

A circular plot of $20-\mathrm{m}$ radius $\left(1256 \mathrm{~m}^{2}\right)$ was established in each unit. Living trees in each plot were calipered in concentric circular areas with a radius of 4,13 and $20 \mathrm{~m}$, with thresholds of minimum diameter at breast height (DBH) of 2.5, 10 and $50 \mathrm{~cm}$, respectively. Height was measured using a Haglof Vertex on one out of ten sampled trees, chosen randomly. For the remaining trees, the height was estimated with a traditional $\mathrm{H}=\mathrm{f}(\mathrm{DBH})$ model calculated on the basis of the trees whose height was measured. In the intermediate circular area $(13 \mathrm{~m}$ radius), the length and diameter of all the lying deadwood components (with a minimum diameter $>10 \mathrm{~cm}$ ) were measured, as well as their decay level according to Hunter (1990). The age of each stand was estimated in the field by expert opinion on the basis of evidence of past disturbance or harvest, as well 
as on the mean size of canopy trees. Age was assigned to one out of six broad classes (1: 50 yrs; 2 : 50-80; 3: 80-100; 4: 100-120; 5: 120-140; and 6: $>140$ yrs old). Stands were classified according to their management type and structure in the following groups: single-, double-, and multi-layer high forests, and coppices. The distribution of estimated ages across forest types is reported in Fig. S4 (Appendix 4). For a more detailed description of the forest structure data collection and preliminary analysis, see Blasi et al. (2010) and Burrascano et al. (2011).

As an additional dataset, we selected 10 beech-dominated stands in central Italy with old-growth features (such as high density of large living trees, high amount of deadwood, uneven-aged structure), whose high structural heterogeneity was previously reported in several studies (Piovesan et al. 2005, Burrascano et al. 2008, Lombardi et al. 2010, Sabatini et al. 2010, 2014, Calamini et al. 2011, Travaglini et al. 2012). Information on location, climate, underlying bedrock and time since last disturbance of these stands is provided in Tab. S1 and Fig. S1.1 (Appendix 1).

Living trees and deadwood were sampled within a 1 ha plot in all the study sites except two (Cozzo Ferriero, 0.16 ha; Fosso Cecita $0.45 \mathrm{ha}$ ), in which plot size was reduced because of the very steep slopes. The position, species, DBH (minimum threshold of $3 \mathrm{~cm}$ ) and height of every tree in the plot were recorded, as well as the position, diameter and length (or height) of standing dead trees, downed dead trees, snags and stumps. Deadwood pieces were sampled if they met the following requirements: minimum diameter $>5 \mathrm{~cm}$, more than half the base of their thicker end lying within the plot, length $>1$ $m$. Further details are reported by Lombardi et al. (2010) and Calamini et al. (2011).

\section{Selection of structural variables to be included in the Index}

An index of structural heterogeneity was built according to the methodology proposed by McElhinny et al. (2006). This four-stage approach starts from (i) the definition of a comprehensive suite of structural attributes that are (ii) then sampled and analyzed in order to (iii) identify a core set of attributes and (iv) combine them into an index.

We compiled a preliminary list of 23 structural variables that may easily be derived from routinely collected data in forest monitoring programmes and NFIs (Chirici et al 2011). This list comprised: (1) basal area; (2) growing stock; (3) number of $\mathrm{DBH}$ classes; (4) DBH diversity (calculated using the Gini-Simpson Index); (5) DBH range; (6) number of living trees with $\mathrm{DBH}>40 \mathrm{~cm}$; (7) tree species richness; (8) quadratic mean DBH; (9) living stem density; (10) height (11) height standard deviation; (12) snags volume; (13) standing dead trees volume; (14) Total standing deadwood volume; (15) density of standing deadwood (both snags and standing dead trees); (16) basal area of standing deadwood (both snags and standing dead trees); (17) stumps volume; (18) lying coarse woody debris volume; (19) the logarithm of the sum of the lengths of lying coarse woody debris pieces (hereafter referred to as "total log length"); (20) total deadwood volume; (21) ratio between deadwood and living wood volumes; (22) number of decay classes occurring in the plot; (23) coarse woody debris index (CWDI, see Appendix 2 for calculation according to $\mathrm{Mc}-$ Elhinny et al. 2006).

To define the suite of attributes to be considered in the final core set of attributes, we first listed the main sources of structural complexity occurring in beech natural forests, as reported in recent literature on oldgrowth forests in southern Europe (Piovesan et al. 2005, Bianchi et al. 2011, Calamini et al. 2011, Motta et al. 2011, Travaglini et al. 2012, Lombardi et al. 2012, Rugani et al. 2013, Sabatini et al. 2014). We considered above all sources of heterogeneity correlating with other desirable properties, e.g., plant and fungi biodiversity, faunal habitat availability and carbon stocking (Houghton 2005, Burrascano et al. 2008, Blasi et al. 2010, Taboada et al. 2010, Hatanaka et al. 2011, Zotti et al. 2013). Eight sources of structural complexity were considered: (1) vertical heterogeneity; (2) compositional diversity; (3) uneven-agedness; (4) density of large living trees; (5) growing stock; (6) total deadwood volume; (7) deadwood decay classes; (8) standing dead trees and snags. A brief description of these elements and how they relate to other ecosystem properties are reported in Tab. 1.

When designing an index of structural complexity, one should focus on attributes that: (i) have a low kurtosis, since a high kurtosis would indicate similar values of an attribute for several sites; (ii) may help to distinguish between categories of interest (e.g., early- versus late-successional stands); (iii) are proxies of other variables or originally contribute to the overall structural stand complexity; (iv) are easily measurable in the field (McElhinny et al. 2006, Chirici et al. 2011).

Both logarithm and square-root transformations were applied to improve the distribution of attributes showing a high kurtosis $(<2)$ : in the selection stage, we only retained the transformation that most improved their distribution.

Since we assumed that structural complexity increases with age, early- and late-successional stands were separated choosing an age threshold of 100 years (which represents the usual harvest return interval for beech forests in the Apennines) and then com- pared. Differences between the two mentioned groups were tested for each structural variable by Mann-Whitney test.

Pairwise correlation between variables was calculated using the Spearman's $\rho$ coefficient. To visualize the multi-correlation structure of variables and evaluate their redundancy, we performed a Principal Components Analysis (PCA) and represented it in Gabriel's plots (only the first 2 principal components, accounting for $42.3 \%$ of the total variance, are shown in Fig. 2).

To help in variable selection, we also estimated whether they were more or less difficult to sample and/or calculate. Variables that only need tree diameter data (e.g., GiniSimpson's diversity, basal area) were considered having a sampling efficiency higher than variables requiring the estimation of other parameters, such as tree height or deadwood debris decay class. To this purpose, variables were grouped in 3 sampling efficiency classes (1: low to 3 : high). When selecting between two or more highly correlated variables to be included in the index, those with a high sampling efficiency were favored (see Appendix 3).

Finally, we created a core set of structural attributes that included a variable for each of the eight sources of structural complexity listed in Tab. 1. Considering the first source of structural complexity (VH), the variable best describing this feature (height standard deviation) was included, provided that it matched the four selection criteria listed above. A similar procedure was adopted for the next sources of structural complexity until all eight sources were represented in the core set. We took tha additional care that the new variable added to the set had the lowest correlation with the variables included in the previous steps. If no variable matched all the selection criteria for a given source of complexity, variables showing low kurtosis and low correlation with those already included were favored. The eight structural variables included in the core set are listed in Tab. 2.

\section{Construction of a Structural \\ Heterogeneity Index (SHI)}

A score ranging from 0 to 10 was assigned to each attribute in the core set based on linear regression through quartiles (Tab. 3). We first set a score of $2.5,5,7.5$ and 10 to the quartile midpoints (corresponding to the $12.5,37.5,62.5$ and 87.5 percentiles, respectively) of the raw attribute distribution. Then, a linear regression through quartile values was fitted to ensure that the attribute scores were evenly distributed between 0 and 10. This regression equation was used to associate a score with each observation. Regression was constrained between 0 and 10 to prevent extremely low and high values from taking scores outside the range. The maximum attribute score of 10 was attri- 
Tab. 1 - List of the eight sources of structural heterogeneity considered in the present study and their ecological importance for forest biodi versity. This list represents the basis to select the structural attributes for constructing the SHI (Structural Heterogeneity Index).

\begin{tabular}{|c|c|c|}
\hline $\begin{array}{l}\text { Sources of } \\
\text { structural } \\
\text { heterogeneity }\end{array}$ & Description & References \\
\hline $\begin{array}{l}\text { Vertical } \\
\text { heterogeneity } \\
\text { (VH) }\end{array}$ & $\begin{array}{l}\text { Stands containing a variety of tree heights are likely to contain a variety of tree ages and, con- } \\
\text { sequently, a high vertical and horizontal heterogeneity. Horizontal and vertical patterns of } \\
\text { trees significantly affect demographic processes, resource distribution (e.g., light), and under- } \\
\text { story development. }\end{array}$ & $\begin{array}{l}\text { Burrascano et al. 2013, Hao } \\
\text { et al. } 2007 \text {, Staudhammer \& } \\
\text { LeMay } 2001\end{array}$ \\
\hline $\begin{array}{l}\text { Compositional } \\
\text { diversity }(\mathrm{CH})\end{array}$ & $\begin{array}{l}\text { The presence of a mix of shade-tolerant and shade-intolerant tree species may produce a } \\
\text { multi-layered canopy. Compositionally diverse tree layers may favour herb-layer diversity, } \\
\text { since different tree species may have different light transmittance and litter quality. }\end{array}$ & $\begin{array}{l}\text { Barbier et al. 2008, Barbier } \\
\text { et al. 2009, Burrascano et al. } \\
2011 \text {, Hatanaka et al. } 2011\end{array}$ \\
\hline $\begin{array}{l}\text { Uneven- } \\
\text { agedness (UA) }\end{array}$ & $\begin{array}{l}\text { In forested landscapes where small to intermediate scale disturbance events are dominant, an } \\
\text { uneven-aged structure may indicate a natural development of the stand, or the application of } \\
\text { close-to-nature silvicultural practices. The variability in tree size may also be an indicator of } \\
\text { the diversity of niches occurring within a stand that could be used by a wealth of animal and } \\
\text { plant organisms. }\end{array}$ & $\begin{array}{l}\text { Keeton 2006, Hatanaka et al } \\
2011\end{array}$ \\
\hline $\begin{array}{l}\text { Density of } \\
\text { large living } \\
\text { trees (LLT) }\end{array}$ & $\begin{array}{l}\text { Large living trees store a large amount of carbon and provide habitat functions for a number } \\
\text { of threatened or ecologically important forest species. These functions relate to the great va- } \\
\text { riety of niches that large trees offer, including rough bark, trunk hollows, exposed deadwood, } \\
\text { sapflows, dead branches and dead tops. }\end{array}$ & $\begin{array}{l}\text { Brunialti et al. 2010, Per- } \\
\text { siani et al. 2010, Nilsson et } \\
\text { al. } 2002\end{array}$ \\
\hline $\begin{array}{l}\text { Growing } \\
\text { stock (GS) }\end{array}$ & $\begin{array}{l}\text { Higher living above-ground biomass indicates the degree to which a stand effectively accom- } \\
\text { plishes its function of storing carbon. Owing to greater levels of biomass, old-growth stands } \\
\text { were shown to attenuate surface temperature more effectively than managed stands, hosting a } \\
\text { higher proportion of forest specialist herb-layer species }\end{array}$ & $\begin{array}{l}\text { Houghton 2005, Hoover et } \\
\text { al. 2012, Norris et al. } 2012\end{array}$ \\
\hline $\begin{array}{l}\text { Total dead- } \\
\text { wood volume } \\
\text { (DW-TOT) }\end{array}$ & $\begin{array}{l}\text { Deadwood is a key ecosystem feature supporting high levels of biodiversity, for instance pro- } \\
\text { viding diverse niches for many specialized and saproxylic organisms. Such organisms include } \\
\text { those with low dispersal capabilities that need long-term availability of deadwood substrate, } \\
\text { whose absence in intensively managed stands may cause local or regional extinction of sev- } \\
\text { eral species. }\end{array}$ & $\begin{array}{l}\text { Castagneri et al. 2010, Las- } \\
\text { sauce et al. 2011, Zotti et al. } \\
2013\end{array}$ \\
\hline $\begin{array}{l}\text { Deadwood } \\
\text { decay classes } \\
(\mathrm{DW}-\mathrm{DC})\end{array}$ & $\begin{array}{l}\text { The absence of deadwood in one or several decay phases strongly indicates a break in the } \\
\text { continuity of deadwood supplies, typically due to a combination of recent harvesting and } \\
\text { deadwood removal. This may affect the continuity of nutrient supply to the forest floor, and } \\
\text { the diversity and abundance of saproxylic organisms. }\end{array}$ & $\begin{array}{l}\text { Lombardi et al. } 2011 \text {, Bur- } \\
\text { rascano et al. } 2008, \text { Las- } \\
\text { sauce et al. } 2011\end{array}$ \\
\hline $\begin{array}{l}\text { Standing dead- } \\
\text { wood, dead } \\
\text { trees and snags } \\
\text { (DW-ST) }\end{array}$ & $\begin{array}{l}\text { Standing dead trees and snags may bear niches such as tree hollows, cavity strings and cracks } \\
\text { that are important for a variety of species such as breeding birds, mammals and invertebrates, } \\
\text { as well as for lichens and bryophytes. }\end{array}$ & $\begin{array}{l}\text { Brunialti et al. 2010, } \\
\text { Hatanaka et al. } 2011\end{array}$ \\
\hline
\end{tabular}

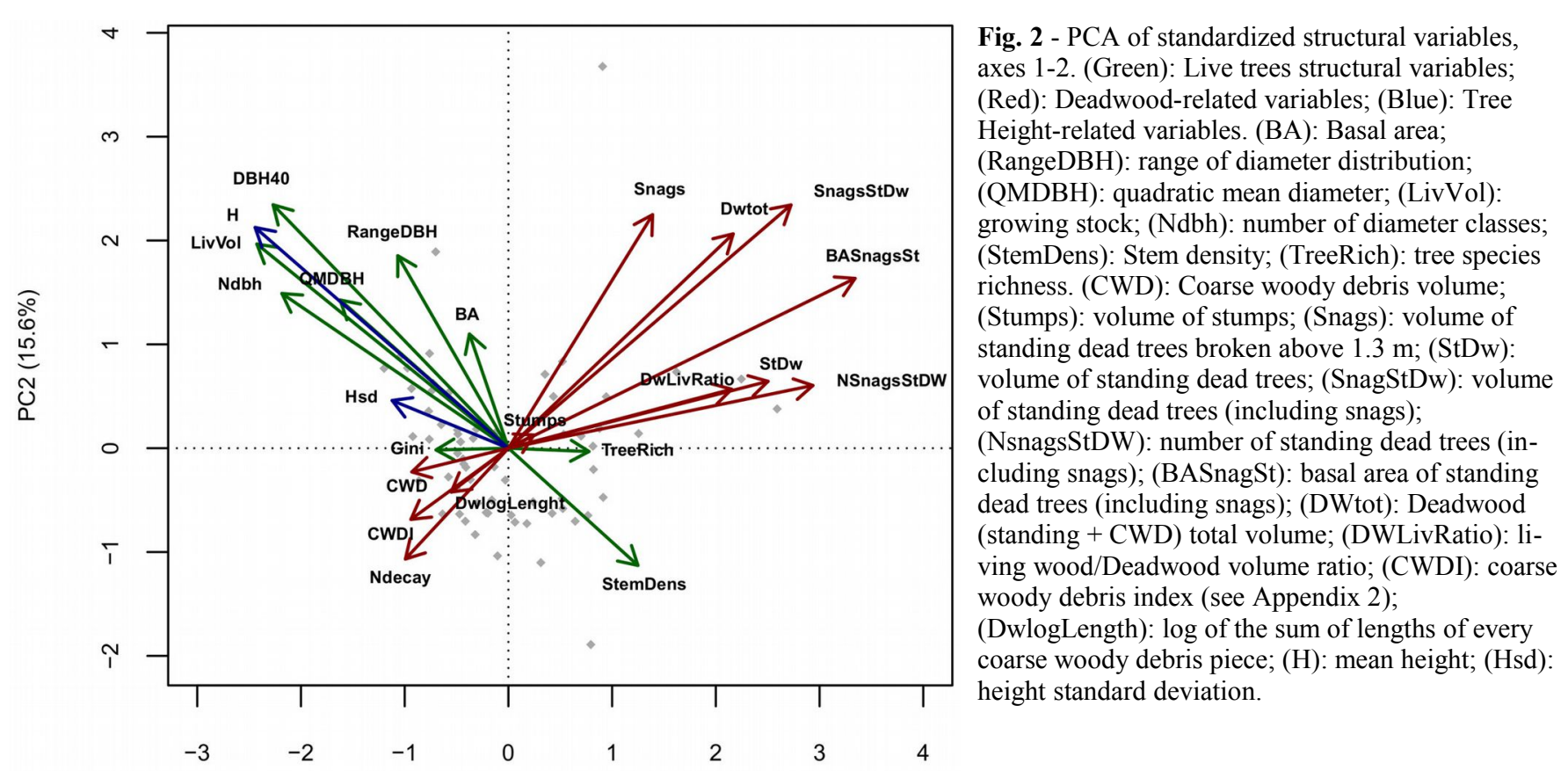


Tab. 2 - Core set of structural variables and selection criteria. (W): Wilcoxon test (equivalent to Mann-Whitney); (Source): the source of he terogeneity indicates whether the variable could be a proxy of one of the eight features described in Tab. 1; (VH): vertical heterogeneity; $(\mathrm{CH})$ : composition heterogeneity; (UA): uneven-agedness; (LLT): occurrence of large living trees; (GS): high growing stock; (DW-TOT): occurrence of a relatively high deadwood volume; (DW-DC): occurrence of deadwood in different decay classes; (DW-ST): occurrence of standing deadwood, dead trees and snags. Sampling efficiency: 1 - poor, 2 - medium, 3 - high.

\begin{tabular}{|c|c|c|c|c|c|c|c|c|}
\hline \multirow{2}{*}{$\begin{array}{l}\text { Structural } \\
\text { indicators }\end{array}$} & \multirow[b]{2}{*}{ Kurtosis } & \multicolumn{4}{|c|}{ Medians } & \multirow{2}{*}{$\begin{array}{l}\text { Function as a surrogate } \\
\text { (significant } \rho>0.5 \text { ) }\end{array}$} & \multirow[b]{2}{*}{ Source } & \multirow{2}{*}{$\begin{array}{l}\text { Sampling } \\
\text { efficiency }\end{array}$} \\
\hline & & $\begin{array}{l}<100 \text { yrs } \\
(n=26)\end{array}$ & $\begin{array}{c}>100 \text { yrs } \\
(n=38)\end{array}$ & $\mathbf{W}$ & Prob. & & & \\
\hline $\begin{array}{l}\text { Living } \\
\text { volume }\end{array}$ & 0.23 & 421.17 & 524.38 & 330 & 0.025 & $\begin{array}{l}\text { Basal Area (0.53); no. DBH classes ( } 0.53) \text {; no. } \\
\text { trees DBH> } 40 \mathrm{~cm}(0.68) \text {; Height }(0.67)\end{array}$ & GS & 1 \\
\hline $\begin{array}{l}\text { no. trees } \\
\mathrm{DBH}>40 \mathrm{~cm}\end{array}$ & -0.11 & 1 & 6.5 & 186 & 0.001 & $\begin{array}{l}\text { Living volume (0.66); DBH range (0.66); Height } \\
(0.78) \text {; Density of standing deadwood }(-0.55) \text {; } \\
\text { Basal area of standing deadwood }(-0.50)\end{array}$ & LLT & 3 \\
\hline $\begin{array}{l}\text { Diameter } \\
\text { diversity } \\
\text { (Gini-Simpson } \\
\text { index) }\end{array}$ & -0.81 & 0.6 & 0.72 & 575 & 0.273 & $\begin{array}{l}\text { Living stem density (-0.64); Quadratic mean } \\
\text { DBH (0.71) }\end{array}$ & UA & 2 \\
\hline $\begin{array}{l}\text { Height stan- } \\
\text { dard deviation }\end{array}$ & -0.34 & 3.53 & 5.47 & 321 & 0.018 & - & VH & 2 \\
\hline CWD index & -0.99 & 2 & 2 & 516.5 & 0.754 & $\begin{array}{l}\text { Lying CWD Volume }(0.85) \text {; no. decay classes } \\
(0.75) \text {; Total log length }(0.86)\end{array}$ & DW-DC & 1 \\
\hline $\begin{array}{l}\log (\text { Tree } \\
\text { species rich- } \\
\text { ness) }\end{array}$ & 0.17 & 1.1 & 0.69 & 573.5 & 0.229 & - & $\mathrm{CH}$ & 3 \\
\hline $\begin{array}{l}\text { log (basal area } \\
\text { of standing } \\
\text { deadwood) }\end{array}$ & -0.31 & 0.85 & 0.18 & 323.5 & 0.018 & $\begin{array}{l}\text { Height }(-0.50) \text {; Snags volume }(0.68) \text {; Standing } \\
\text { dead trees volume }(0.86) \text {; Total Standing dead- } \\
\text { wood }(0.98) \text {; Total deadwood }(0.73) \text {; Density of } \\
\text { standing deadwood }(0.89) \text {; Dead/Living wood } \\
\text { ratio }(0.76)\end{array}$ & DW-ST & 3 \\
\hline $\begin{array}{l}\text { sqrt (total } \\
\text { deadwood) }\end{array}$ & 0.04 & 4.7 & 4.63 & 526.5 & 0.662 & $\begin{array}{l}\text { Standing dead trees volume }(0.65) \text {; Total Stand- } \\
\text { ing deadwood }(0.77) \text {; Density of standing dead- } \\
\text { wood }(0.68) \text {; Basal area of standing deadwood } \\
(0.61) \text {; Dead/Living wood ratio }(0.96)\end{array}$ & DW-TOT & 1 \\
\hline
\end{tabular}

buted to the 87.5 percentile. Compared with a simple scaling of values in the range -1 to 1 , the above technique has the advantage of avoiding possible distortions due to the occurrence of extremely high or low outliers, and yielding a more even distribution of index scores across the range of variability of the raw attributes.

Finally, a Structural Heterogeneity Index (SHI) was obtained by summing the scores in the range $0-10$ assigned to each variable in the core set, and then expressed as a percentage. Score weighting was not considered here because: (i) it could imply an arbitrary choice; (ii) index performances were found to be independent of the weighting of attributes (McElhinny et al. 2006); (iii) an unweighted index provides a clearer picture of the relative contribution of different sources of heterogeneity.

\section{Testing the Structural Heterogeneity Index}

SHI values calculated for the 64 forest plots in the Cilento National Park were tested for significant differences between broad classes based on age and management type using non-parametric Kruskal-Wallis test. We used multiple regression to test whether the SHI significantly increases with age, and covariates with management type as well as with other environmental attributes (i.e., altitude, slope, aspect). Backwards selection was applied to discard non-significant terms.

As an additional evaluation of index performances, we calculated the SHI on the set of 10 beech-dominated, old-growth forests from central Italy (Fig. S1.1, Tab. S1 - Appendix 1), whose structural data were not used during the calibration process. SHI values of such forests were compared with those obtained for plots in early-mature to mature stands in the Cilento National Park. We tested for significant differences by

means of the Kruskal-Wallis test.

All analyses were performed using the software package R 2.14.1 (R Development Core Team 2011).

\section{Results}

Beech stands in the Cilento National Park showed index values ranging between 38 and 79.1 (median 59.4) and showing no departure from normal distribution (Fig. S5.1). The SHI appeared to have a minimum in the 80 year-age class, and a slow increase with age (Fig. 3A). A high variability of SHI values was observed within each age class, and no significant differences among classes

Tab. 3 - Regression equations used to assign a score to attributes on a scale of $0-10$, obtained from 64 beech dominated forest stands in the Cilento, Vallo di Diano e Alburni National Park, southern Italy. For more details, see Materials and Methods.

\begin{tabular}{lll}
\hline Attribute & Regression equation & $\mathbf{R}^{2}$ \\
\hline Living volume & Score $=-2.021+\mathrm{X} \cdot 0.016$ & 0.938 \\
no. Large Living Trees DBH $>40 \mathrm{~cm}$ & Score $=3.274+\mathrm{X} \cdot 0.595$ & 0.952 \\
DBH diversity (Gini-Simpson index) & Score $=-2.233+\mathrm{X} \cdot 14.034$ & 0.969 \\
Height standard deviation & Score $=1.815+\mathrm{X} \cdot 0.811$ & 0.918 \\
CWD index & Score $=3.750+\mathrm{X} \cdot 1.25$ & 0.900 \\
Log (Tree species richness) & Score $=-2.511+\log (\mathrm{X}) \cdot 9.053$ & 0.900 \\
Log (basal area of standing deadwood) & Score $=3.536+\log (\mathrm{X}) \cdot 4.221$ & 0.924 \\
sqrt (Total deadwood volume) & Score $=1.167+\operatorname{sqrt}(\mathrm{X}) \cdot 1.083$ & 0.999 \\
\hline
\end{tabular}


A

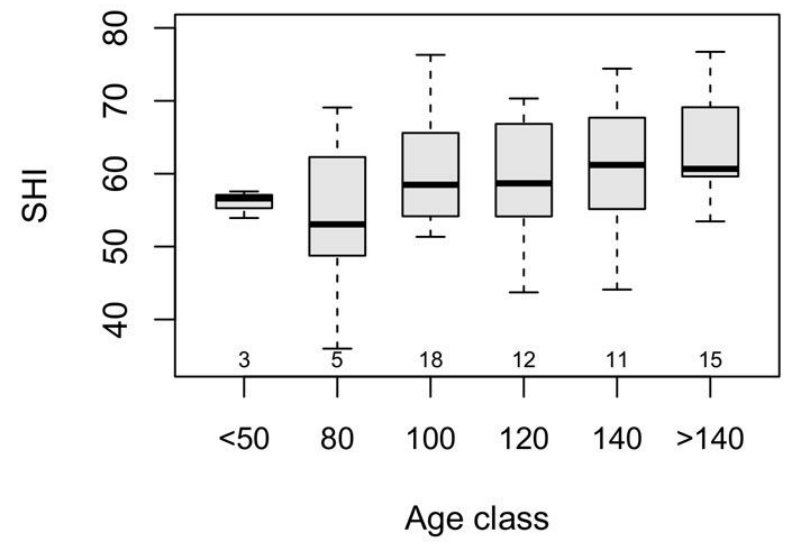

B

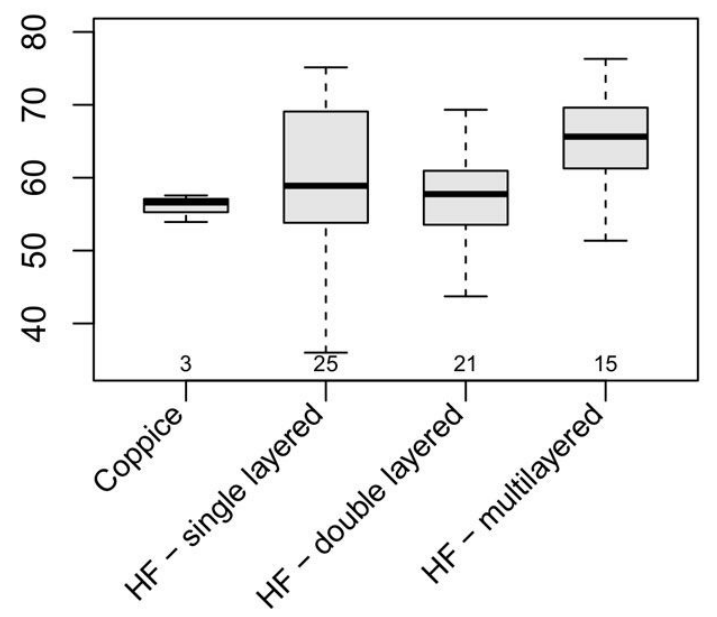

Fig. 3 - Boxplot of SHI across age classes (A) and structural types (B). Small numbers below the boxes represent the sample size. (HF): High forest.

Fig. 4 - SHI comparison between early-mature to mature, and old-growth stands.

The boxplots refer to the

SHI of managed beech

forests in the Cilento $\mathrm{Na}$ tional Park (left) with those of a set of beech forests with old-growth features located throughout the Apennines (right). Small numbers below the boxes represent the sample size.

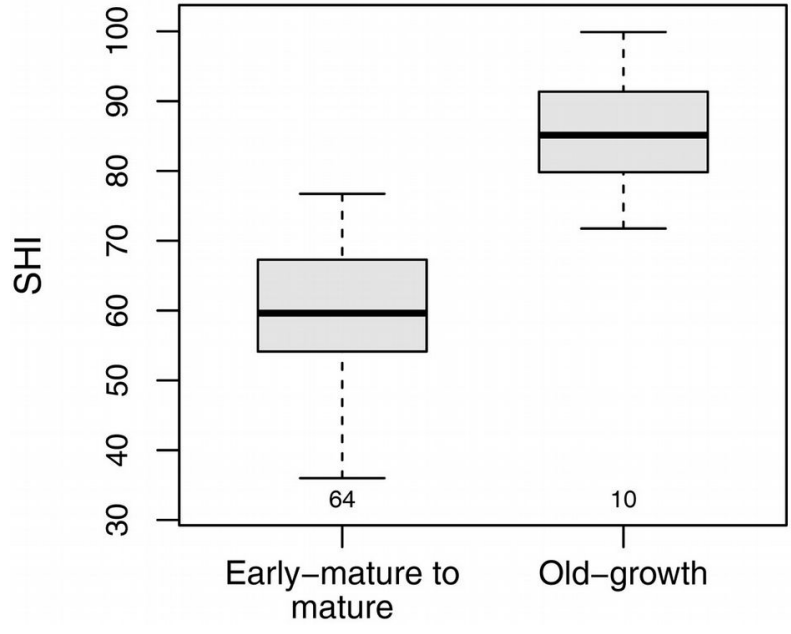

(Kruskal-Wallis $\mathrm{H}=6.08, \mathrm{df}=5, \mathrm{p}=0.297$ ). On the other hand, the SHI significantly differed across management types $(\mathrm{H}=10.39$, $\mathrm{df}=3, \mathrm{p}=0.015)$. However, the only significant $(\mathrm{p}<0.05)$ difference using post-hoc mul- tiple comparison was detected between multi-layer and double-layer high forests (Fig. 3B). Multiple regression showed a significant linear increase in the SHI with stand age $\left(b=0.064, \mathrm{t}_{(61)}=2.48, \mathrm{p}=0.015\right)$ and a ne- gative relationship with altitude $(b=-0.022$, $\left.\mathrm{t}_{(61)}=-3.31, \mathrm{p}=0.002\right)$. Adjusted- $\mathrm{R}^{2}$ was 0.19 . Based on the above analysis, neither management type, nor the interaction between management type and age, were significant predictors of the SHI.

Structural heterogeneity of a set of Italian beech old-growth forests

The SHI of the selected old-growth stands ranged between 71.7 and 99.9 (median 85.1). The SHI was significantly higher for reference old-growth stands than for the beech stands included in the main dataset $(\mathrm{H}$ $=27.7, \mathrm{df}=2, \mathrm{p}<0.001$ - Fig. 4, Tab. 4).

The high SHI values observed in the oldgrowth stands stem from the high scores of index subcomponents, whose relative importance varied greatly across stands (Tab. 4). According to the SHI, each of the 10 oldgrowth stands was structurally heterogeneous in a unique way; the most important sources of SHI variability among old-growth stands were living volume, tree height stan-

Tab. 4 - SHI values and scores for its sub-components calculated for 10 beech stands with old-growth features located throughout the Apennines. Scores for each structural variable was obtined by the regression equations reported in Tab. 3. SHI was calculated as the sum of variable scores, normalized on a percent basis.

\begin{tabular}{|c|c|c|c|c|c|c|c|c|c|}
\hline Stand & $\begin{array}{c}\text { Living } \\
\text { volume }\end{array}$ & $\begin{array}{c}\text { No. trees } \\
\text { DBH }>40 \mathrm{~cm}\end{array}$ & $\begin{array}{l}\text { DBH diversity } \\
\text { (Gini-Simpson) }\end{array}$ & $\begin{array}{c}\text { Height } \\
\text { sd }\end{array}$ & $\begin{array}{l}\text { CWD } \\
\text { index }\end{array}$ & $\begin{array}{c}\text { Log } \\
\text { (tree sp. } \\
\text { richness) }\end{array}$ & $\begin{array}{c}\text { Log } \\
\text { (BA stand } \\
\text { dw) }\end{array}$ & $\begin{array}{c}\text { Sqrt } \\
\text { (total dw) }\end{array}$ & SHI \\
\hline Abeti Soprani & 6.9 & 10.0 & 10.0 & 6.8 & 10.0 & 10.0 & 9.4 & 10.0 & 91.4 \\
\hline Collemeluccio & 6.7 & 10.0 & 10.0 & 6.6 & 10.0 & 10.0 & 4.8 & 5.7 & 79.8 \\
\hline Cozzo Ferriero & 10.0 & 10.0 & 10.0 & 8.4 & 10.0 & 0.0 & 7.1 & 10.0 & 81.8 \\
\hline Fonte Novello & 10.0 & 10.0 & 10.0 & 7.3 & 10.0 & 0.0 & 10.0 & 10.0 & 84.1 \\
\hline Gargano-Pavari & 8.4 & 10.0 & 10.0 & 10.0 & 10.0 & 7.4 & 9.1 & 10.0 & 93.7 \\
\hline Monte Cimino & 10.0 & 10.0 & 9.3 & 10.0 & 10.0 & 10.0 & 5.0 & 7.3 & 89.5 \\
\hline Monte di Mezzo & 9.0 & 10.0 & 10.0 & 7.8 & 10.0 & 10.0 & 5.4 & 6.7 & 86.2 \\
\hline Monte Sacro & 5.3 & 10.0 & 8.3 & 7.9 & 10.0 & 0.0 & 5.9 & 10.0 & 71.7 \\
\hline Sasso Fratino & 10.0 & 10.0 & 10.0 & 10.0 & 10.0 & 10.0 & 10.0 & 9.9 & 99.9 \\
\hline Val Cervara & 3.7 & 10.0 & 8.6 & 8.6 & 10.0 & 0.0 & 10.0 & 10.0 & 76.1 \\
\hline
\end{tabular}


dard deviation, canopy tree species richness and basal area of standing deadwood. For instance, living volume greatly varied across the 10 old-growth stands, probably as a result of differences in altitude, site fertility and time since last disturbance. Although "Val Cervara" is probably the best preserved old-growth beech stands in central Apennines, this stand only attained a very low score for living volume (3.7 out of 10), when compared with other stands located at lower altitudes and in more favorable site conditions (e.g., "Fonte Novello" or "Monte Cimino") The basal area of standing deadwood also strongly varied across stands (from 4.8 in "Collemeluccio" to 10 in "Fonte Novello", "Sasso Fratino" and "Val Cervara"). Species richness of the tree layer varied markedly and clearly distinguished between pure beech stands (e.g., "Fonte Novello", "Val Cervara") and beech stands mixed with other taxa such as Abies alba (e.g., "Abeti Soprani", "Sasso Fratino"), or other broadleaved species, such as Ilex aquifolium and Acer obtusatum in "Gargano-Pavari", or A. obtusatum and A. pseudoplatanus in "Monte Cimino".

\section{Discussion}

\section{Management, disturbance history, and environmental factors contribute to current forest heterogeneity}

We applied an acknowledged methodology to obtain an index of structural heterogeneity for southern Italy beech forests. Forest structural heterogeneity, as indicated by the SHI, linearly increased with stand age and was higher for multi-layer high forests than for single- and double-layer forests.

The positive relationship between the SHI and stand age closely matched our expectations, although there was a marked variability both within management types and age classes. Such variability was likely due to the wide range of site conditions, soil fertility, disturbance and forest management histories found in the study area. In particular, the SHI revealed a very high degree of variation in single- and double-layer high forests. These management types encompassed stands with highly variable amounts of growing stock (whose index sub-scores ranged between 2 and 10 for single-layered and between 1.1 and 10 for double-layered stands), height standard deviations (scores ranging between 2.6-10 and 3.3-10, respectively) and coarse woody debris volumes (1.1-10 and 1.1-9.4, respectively).

Although part of this variability can be accounted for by differences in age classes and altitude, the relationship observed between stand age and complexity should be considered only as a general trend. Since the management history of most stands is only partially known (harvest archives in most muni- cipalities of the study area date back no longer than the 1990s), stands were only classified into broad age classes on the basis of expert opinion. More detailed stand age data, including accurate dendrochronological reconstructions of their past disturbances, would be required to quantify the actual rate at which forest complexity increases over time.

Besides stand age, most of the remaining variability is likely to be dependent on the different disturbance and harvesting histories of these stands. Forests in southern Italy are characterized by a peculiar history: in the $19^{\text {th }}$ century, a forest law prescribed clearcuts with the release of 45 standards per hectare to be applied indistinctly to all the forests of the Kingdom of the two Sicilies (which included southern Italy and Sicily). However, this law was never extensively applied, and most of the forests continued to be subject to selective cuttings (Gualdi \& Tartarino 2006), even well into the $20^{\text {th }}$ century. Although the shelterwood system began to be applied regularly to the Apennine beech forests in the $20^{\text {th }}$ century, beech forests in southern Italy have been frequently managed according to models based on "local knowledge", resulting in a wide range of silvicultural and harvesting practices that have contributed to the current variability of the forest structures in the study area.

\section{Use of SHI for the classification of old-} growth forests

In an operational context, structural indicators may prove very useful to distinguish old-growth forests from younger developmental stages, as well as to rank forests along "old-growthness" gradients (Lindenmayer et al. 2000, Franklin et al. 2002). However, old-growth characteristics should be defined not only on the basis of a set of structures providing desirable functions, but also based on the developmental processes producing such structures. The SHI does not discriminate the process (anthropogenic vs. natural) that resulted in a certain amount of heterogeneity accumulating in a stand. $\mathrm{Ne}$ vertheless, we believe this index may be useful for assessing how far a stand is from reference old-growth characteristics, but only when no further information on long-term disturbance history is available.

Recently, Chiavetta et al. (2012) have attempted to rank Italian beech forests on a scale of "old-growthness" based on the multivariate dissimilarity of studied stands from a reference virtual old-growth stand whose structural attributes were derived from the literature. In our opinion, this is an interesting approach, though suffering from the fact that literature data on old-growth structural variability is either very scarce or completely lacking for most forest types in Europe, and reference attributes had to be derived from unrelated biogeographical regions. Unlike the above approach, the SHI was only based on the structural variability observed in the study region, as suggested by McElhinny et al. (2006), and on a list of desirable features widely recognized as important sources of heterogeneity in old-growth stands. Therefore, the SHI is less likely to be subject to bias deriving from incorrect assumptions.

In this study, old-growth stands showed very high SHI values, sometimes close to the maximum as in the case of the "Sasso Fratino" stand. This result confirmed that this index effectively captures aspects of structural heterogeneity recognized as important in reference beech old-growth forests in southern Europe (Piovesan et al. 2005, Motta et al. 2011, Rugani et al. 2013, Sabatini et al. 2014). The core set of structural attributes considered here may be further expanded including other significant sources of complexity, such as gap fraction, diversity of shrubs or other vascular plants, or litter distribution variability. However, a trade-off exists between the relevance of information included in the index and its cost in terms of time or expertise required (Chirici et al. 2011, McRoberts et al. 2012). In this study, we chose to include in the SHI only those structural variables that can easily be obtained from routinely collected data in plotbased forest inventories, with no need of vegetation surveys (e.g., understory diversity or abundance assessments) or analysis on a broader spatial scale (e.g., to estimate forest gap fraction).

Since SHI successfully distinguished between old-growth and younger stands, the question arises whether this index could also be used to assess the "naturalness" of a forest stand. The concept of "naturalness" is related to the degree to which forest ecosystems are characterized by natural processes and/or the absence of human influences (McRoberts et al. 2012). To this regard, the SHI does not include any metrics to measure human impact. In theory, very high SHI values may be obtained also for forest stands deeply modified by silvicultural practices aimed at enhancing its structural complexity. Therefore, we recommend the application of SHI only in studies aimed at assessing the structural heterogeneity of forest stands.

\section{Potential and limitations of the SHI}

There is a great need for simple tools that can help forest managers to improve stand biodiversity (Whitman \& Hagan 2007). To this purpose, the SHI may be useful to test the effectiveness of silvicultural practices aimed at restoring the complexity in secondgrowth stands, by comparing the structural heterogeneity before and after the intervention.

One of the main advantage of the SHI is that it simply consists of the sum of scores 
for each structural attribute, obtaining a "synthetic" index of stand complexity. On the other hand, similar SHI values may mask different underlying source of heterogeneity. This was the case of the "Abeti Soprani" and "Monte Cimino" old-growth stands (Tab. 4), sharing similar SHI values but strongly differing in attributes such as tree height standard deviation, basal area of standing deadwood and total deadwood volume. However, the additive structure of the SHI may help forest managers to assess the relative contribution of each attribute to overall stand heterogeneity, thereby helping to prioritize specific silvicultural interventions aimed at increasing forest structural complexity. This is particularly relevant in the context of adaptive management.

The SHI relies upon input data routinely acquired by almost all the NFIs in the world (Chirici et al. 2011). Therefore, it may be appiled to stands from a wide range of biogeographical regions (Chirici et al. 2012). So far, we tested its performance on a relatively wide set of forest stands, encompassing all the climatic, topographical and soil variability found in beech forests in the Cilento $\mathrm{Na}$ tional Park. However, before its use in other contexts, we recommend a fine-tuning of the SHI on an adequately comprehensive dataset, such as that from the last Italian natio nal forest inventory (Gasparini \& Tabacchi 2011).

Forest structural indicators may also be sensitive to the field methods used for their assessment, such as plot size and minimum DBH thresholds (McRoberts et al. 2012, Chirici et al. 2012). The need for harmonization procedures in the calculation of structural indexes from different field acquisitions has often been advocated (Ståhl et al. 2012). In our study, we used two different datasets that had consistently similar deadwood and living wood diameter thresholds, but a substantially different plot size $\left(1256 \mathrm{~m}^{2} v s .1\right.$ ha). This may represent a potential source of bias, though we do not expect this could severely affect our results. Indeed, data collected in small plots may provide an estimation of structural parameters less accurate than those from large plots but, as long as plots are randomly located, an unbiased estimation of structural attributes on a per hectare basis is still obtained. Such difference in precision may be particularly marked when structural attributes associated with relatively rare elements are considered, such as standing dead trees, though the estimation of the SHI will still be substantially unbiased.

In conclusion, indicators based on key structural parameters are of considerable interest as practical surrogates for attributes that are normally too expensive or difficult to measure, such as biodiversity or ecosystem functioning. The common assumption that the structural, functional, and composi- tional attributes of a stand are inter-dependent (Franklin et al. 2002, Hatanaka et al. 2011) requires further testing. Future analyses are needed to assess the performance of the SHI outside the study area and its relationship with several important ecosystem functions, such as forest biodiversity, productivity and resilience, biogeochemical cycles or wildlife food availability.

\section{Acknowledgements}

We thank the Cilento, Vallo di Diano and Alburni National Park for funding this research and the State Forestry Corps for their assistance during the fieldwork. We also wish to thank all the colleagues who took part in the field campaign. FMS and SB conceived the study, FMS performed the statistical analysis, FL and GC provided oldgrowth forests data. FMS, SB, FL, GC and $\mathrm{CB}$ interpreted the data and contributed to the drafting of the manuscript. We would also like to thank our language reviewer Lewis Baker.

\section{References}

Barbier S, Gosselin F, Balandier P (2008). Influence of tree species on understory vegetation diversity and mechanisms involved - A critical review for temperate and boreal forests. Forest Ecology and Management 254: 1-15. - doi: 10.1016/j.foreco.2007.09.038

Barbier S, Chevalier R, Loussot P, Bergès L, Gosselin F (2009). Improving biodiversity indicators of sustainable forest management: tree genus abundance rather than tree genus richness and dominance for understory vegetation in French lowland oak hornbeam forests. Forest Ecology and Management 258: S176-S186. - doi: 10.1016/j.foreco.2009.09.004

Bartels SF, Chen HYH (2009). Is understory plant species diversity driven by resource quantity or resource heterogeneity? Ecology 91: 1931-1938. - doi: 10.1890/09-1376.1

Bianchi L, Bottacci A, Calamini G, Maltoni A, Mariotti B, Quilghini G, Salbitano F, Tani A, Zoccola A, Paci M (2011). Structure and dynamics of a beech forest in a fully protected area in the northern Apennines (Sasso Fratino, Italy). iForest 4: 136-144. - doi: 10.3832/ifor0564-004 Blasi C, Marchetti M, Chiavetta U, Aleffi M, Audisio P, Azzella MM, Brunialti G, Capotorti G, Del Vico E, Lattanzi E, Persiani AM, Ravera S, Tilia A, Burrascano S (2010). Multi-taxon and forest structure sampling for identification of indicators and monitoring of old-growth forest. Plant Biosystems 144: 160-170. - doi: 10.1080/ 11263500903560538

Brunialti G, Frati L, Aleffi M, Marignani M, Rosati L, Burrascano S, Ravera S (2010). Lichens and bryophytes as indicators of old-growth features in Mediterranean forests. Plant Biosystems 144: 221-233. - doi: 10.1080/112635009035609 59

Burrascano S, Lombardi F, Marchetti M (2008). Old-growth forest structure and deadwood: are they indicators of plant species composition? A case study from central Italy. Plant Biosystems 142: 313-323. - doi: 10.1080/112635008021506 13

Burrascano S, Sabatini FM, Blasi C (2011). Testing indicators of sustainable forest management on understorey composition and diversity in southern Italy through variation partitioning. Plant Ecology 212: 829-841. - doi: 10.1007/s11 258-010-9866-y

Burrascano S, Keeton WS, Sabatini FM, Blasi C (2013). Commonality and variability in the structural attributes of moist temperate oldgrowth forests: a global review. Forest Ecology and Management 291: 458-479. - doi: 10.1016/j. foreco.2012.11.020

Calamini G, Maltoni A, Travaglini D, Iovino F, Nicolaci A, Menguzzato G, Corona P, Ferrari B, Di Santo D, Chirici G, Lombardi F (2011). Stand structure attributes in potential old-growth forests in the Apennines, Italy. L'Italia Forestale e Montana 66: 365-381. - doi: 10.4129/ifm.20 11.5.01

Castagneri D, Garbarino M, Berretti R, Motta R (2010). Site and stand effects on coarse woody debris in montane mixed forests of Eastern Italian Alps. Forest Ecology and Management 260: 1592-1598. - doi: 10.1016/j.foreco.2010.08.008 Chiavetta U, Sallustio L, Garfì V, Maesano M, Marchetti M (2012). Classification of the oldgrowthness of forest inventory plots with dissimilarity metrics in Italian National Parks. European Journal of Forest Research 131: 1473-1483. - doi: 10.1007/s10342-012-0622-9

Chirici G, Winter S, McRoberts RE (2011). National forest inventories: contributions to forest biodiversity assessments. Springer, Berlin and Heidelberg, Germany, pp. 206. - doi: 10.1007/9 78-94-007-0482-4

Chirici G, McRoberts RE, Winter S, Bertini R, Brändli U-B, Asensio IA, Bastrup-Birk A, Rondeux J, Barsoum N, Marchetti M (2012). National forest inventory contributions to forest biodiversity monitoring. Forest Science 58: $257-$ 268. - doi: 10.5849/forsci.12-003

Corona P, Chirici G, McRoberts RE, Winter S, Barbati A (2011). Contribution of large-scale forest inventories to biodiversity assessment and monitoring. Forest Ecology and Management 262: 2061-2069. - doi: 10.1016/j.foreco.2011.08. 044

Donato DC, Campbell JL, Franklin JF (2012). Multiple successional pathways and precocity in forest development: can some forests be born complex? Journal of Vegetation Science 23: 576584. - doi: 10.1111/j.1654-1103.2011.01362.x Franklin JF, Spies TA, Van Pelt R, Carey AB, Thornburgh DA, Berg DR, Lindenmayer DB, Harmon ME, Keeton WS, Shaw DC, Bible K, Chen JQ (2002). Disturbances and structural development of natural forest ecosystems with silvicultural implications, using Douglas-fir forests as an example. Forest Ecology and Management 155: 399-423. - doi: 10.1016/S0378-1127(01)00 $575-8$

Gasparini P, Tabacchi G (2011). L'Inventario Na- 
zionale delle Foreste e dei serbatoi forestali di Carbonio INFC 2005 [The national inventory of forests and carbon stocks INFC 2005.]. Secondo inventario forestale nazionale italiano. Metodi risultati. Ministero delle Politiche Agricole, Alimentari e Forestali, Corpo Forestale dello Stato, Consiglio per la Ricerca e la Sperimentazione in Agricoltura, Unità di ricerca per il Monitoraggio e la Pianificazione Forestale, Edagricole-Il Sole 24 ore, Bologna, pp. 653.

Gualdi V, Tartarino P (2006). Altre riflessioni sulla gestione su basi assestamentali della foresta mediterranea europea [Further notes on the management and harvest planning of European $\mathrm{Me}$ diterranean forests]. Italia Forestale e Montana 61: 477-487. [in Italian with English abstract] doi: 10.4129/IFM.2006.6.01

Hao ZQ, Zhang J, Song B, Ye J, Li BH (2007). Vertical structure and spatial associations of dominant tree species in an old-growth temperate forest. Forest Ecology and Management 252: 111. - doi: 10.1016/j.foreco.2007.06.026

Hatanaka N, Wright W, Loyn RH, MacNally R (2011). "Ecologically complex carbon" - linking biodiversity values, carbon storage and habitat structure in some austral temperate forests. Global Ecology and Biogeography 20: 260-271. - doi: 10.1111/j.1466-8238.2010.00591.x

Hoover CM, Leak WB, Keel BG (2012). Benchmark carbon stocks from old-growth forests in northern New England, USA. Forest Ecology and Management 266: 108-114. - doi: 10.1016/j. foreco.2011.11.010

Houghton RA (2005). Aboveground forest biomass and the global carbon balance. Global Change Biology 11: 945-958. - doi: 10.1111/j. 1365-2486.2005.00955.x

Hunter ML (1990). Wildlife, forests and forestry: principles of managing forests for biological diversity. Prentice Hall, Englewood Cliffs, NJ, USA, pp. 270.

Jung K, Kaiser S, Bohm S, Nieschulze J, Kalko EKV (2012). Moving in three dimensions: effects of structural complexity on occurrence and activity of insectivorous bats in managed forest stands. Journal of Applied Ecology 49: 523-531. - doi: 10.1111/j.1365-2664.2012.02116.x

Keeton WS (2006). Managing for late-successional/old-growth characteristics in northern hardwood-conifer forests. Forest Ecology and Management 235: 129-142. - doi: 10.1016/j.foreco.20 06.08.005

Lassauce A, Paillet Y, Jactel H, Bouget C (2011) Deadwood as a surrogate for forest biodiversity: Meta-analysis of correlations between deadwood volume and species richness of saproxylic organisms. Ecological Indicators 11: 1027-1039. doi: 10.1016/j.ecolind.2011.02.004

Lindenmayer DB, Margules CR, Botkin DB (2000). Indicators of biodiversity for ecologically sustainable forest management. Conservation Biology 14: 941-950. - doi: 10.1046/j.1523-173 9.2000.98533.x

Lombardi F, Cocozza C, Lasserre B, Tognetti R, Marchetti M (2011). Dendrochronological assessment of the time since death of dead wood in an old growth Magellan's beech forest, Navarino Island (Chile). Austral Ecology 36: 329-340. doi: 10.1111/j.1442-9993.2010.02154.x

Lombardi F, Lasserre B, Chirici G, Tognetti R, Marchetti M (2012). Deadwood occurrence and forest structure as indicators of old-growth forest conditions in Mediterranean mountainous ecosystems. Ecoscience 19: 344-355. - doi: 10.2980/ 19-4-3506

Lombardi F, Chirici G, Marchetti M, Tognetti R, Lasserre B, Corona P, Barbati A, Ferrari B, Di Paolo S, Giuliarelli D, Mason F, Iovino F, Nicolaci A, Bianchi L, Maltoni A, Travaglini D (2010). Deadwood in forest stands close to oldgrowthness under Mediterranean conditions in the Italian Peninsula. Italia Forestale e Montana 65: 481-504. - doi: 10.4129/ifm.2010.5.02

McElhinny C, Gibbons P, Brack C (2006). An objective and quantitative methodology for constructing an index of stand structural complexity. Forest Ecology and Management 235: 54-71. doi: 10.1016/j.foreco.2006.07.024

McElhinny C, Gibbons P, Brack C, Bauhus J (2005). Forest and woodland stand structural complexity: Its definition and measurement. Forest Ecology and Management 218: 1-24. - doi: 10.1016/j.foreco.2005.08.034

McRoberts RE, Winter S, Chirici G, Lapoint E (2012). Assessing Forest Naturalness. Forest Science 58 (3): 294-309. - doi: 10.5849/forsci.10075

Motta R, Berretti R, Castagneri D, Dukic V, Garbarino M, Govedar Z, Lingua E, Maunaga Z, Meloni F (2011). Toward a definition of the range of variability of central European mixed Fagus-Abies-Picea forests: the nearly steadystate forest of Lom (Bosnia and Herzegovina). Canadian Journal of Forest Research 41: 18711884. - doi: 10.1139/x11-098

Neumann M, Starlinger F (2001). The significance of different indices for stand structure and diversity in forests. Forest Ecology and Management 145: 91-106. - doi: 10.1016/S0378-1127 (00)00577-6

Nilsson SG, Niklasson M, Hedin J, Aronsson G, Gutowski JM, Linder P, Ljungberg H, Mikusinski G, Ranius T (2002). Densities of large living and dead trees in old-growth temperate and boreal forests. Forest Ecology and Management 161: 189-204. - doi: 10.1016/S0378-1127(01) 00480-7

Norris C, Hobson P, Ibisch PL (2012). Microclimate and vegetation function as indicators of forest thermodynamic efficiency. Journal of Applied Ecology 49 (3): 562-570. - doi: 10.1111/j. 1365-2664.2011.02084.x

Persiani AM, Audisio P, Lunghini D, Maggi O, Granito VM, Biscaccianti AB, Chiavetta U, Marchetti M (2010). Linking taxonomical and functional biodiversity of saproxylic fungi and beetles in broad-leaved forests in southern Italy with varying management histories. Plant Biosystems 144: 250-261. - doi: 10.1080/11263 500903561114

Piovesan G, Di Filippo A, Alessandrini A, Biondi F, Schirone B (2005). Structure, dynamics and dendroecology of an old-growth Fagus forest in the Apennines. Journal of Vegetation Science 16 (1): 13-28. - doi: 10.1111/j.1654-1103.2005.tb 02334.x

R Development Core Team (2011). R: a language and environment for statistical computing. R Foundation for Statistical Computing, Vienna, Austria. [online] URL: http://www.r-project.org/ Rugani T, Diaci J, Hladnik D (2013). Gap dynamics and structure of two old-growth beech forest remnants in Slovenia. PLoS ONE 8: e52641. - doi: 10.1371/journal.pone.0052641

Sabatini FM, Burrascano S, Blasi C (2010). Niche heterogeneity and old-growth conservation value. Italia Forestale e Montana 65: 621-636. - doi: 10.4129/IFM.2010.5.10

Sabatini FM, Burrascano S, Tuomisto H, Blasi C (2014). Ground layer plant species turnover and beta diversity in southern-european old-growth forests. PLoS One 9 (4): e95244. - doi: 10.1371/journal.pone.0095244

Schall P, Ammer C (2013). How to quantify forest management intensity in Central European forests. European Journal of Forest Research 132: 379-396. - doi: 10.1007/s10342-013-0681-6

Ståhl G, Cienciala E, Chirici G, Lanz A, Vidal C, Winter S, McRoberts RE, Rondeux J, Schadauer $\mathrm{K}$, Tomppo E (2012). Bridging national and reference definitions for harmonizing forest statistics. Forest Science 58: 214-223. - doi: 10.58 49/forsci.10-067

Staudhammer CL, LeMay VM (2001). Introduction and evaluation of possible indices of stand structural diversity. Canadian Journal of Forest Research 31: 1105-1115. - doi: 10.1139/x01-033 Taboada A, Tarrega R, Calvo L, Marcos E, Marcos JA, Salgado JM (2010). Plant and carabid beetle species diversity in relation to forest type and structural heterogeneity. European Journal of Forest Research 129: 31-45. - doi: 10.1007/ s10342-008-0245-3

Travaglini D, Paffetti D, Bianchi L, Bottacci A, Bottalico F, Giovannini G, Maltoni A, Nocentini S, Vettori C, Calamini G (2012). Characterization, structure and genetic dating of an oldgrowth beech-fir forest in the northern Apennines (Italy). Plant Biosystems 146: 175-188. doi: 10.1080/11263504.2011.650731

Whitman AA, Hagan JM (2007). An index to identify late-successional forest in temperate and boreal zones. Forest Ecology and Management 246: 144-154. - doi: 10.1016/j.foreco.2007.03. 004

Winter S, Moller GC (2008). Microhabitats in lowland beech forests as monitoring tool for nature conservation. Forest Ecology and Management 255: 1251-1261. - doi: 10.1016/j.foreco.20 07.10 .029

Zenner EK, Hibbs DE (2000). A new method for modeling the heterogeneity of forest structure. Forest Ecology and Management 129: 75-87. doi: 10.1016/S0378-1127(99)00140-1

Zotti M, Persiani AM, Ambrosio E, Vizzini A, Venturella G, Donnini D, Angelini P, Di Piazza S, Pavarino M, Lunghini D, Venanzoni R, Polemis E, Granito VM, Maggi O, Gargano ML, Zer- 
vakis GI. (2013). Macrofungi as ecosystem resources: conservation versus exploitation. Plant Biosystems 147: 219-225. - doi: 10.1080/11263 504.2012 .753133

\section{Supplementary Material}

Appendix 1 - Location and synthetic description of 10 old-growth stands used to evaluate the performance of the SHI. Link: Sabatini1160@supp1001.pdf

Appendix 2 - Construction of the CWD index.

Link: Sabatini_1160@supp1002.pdf
Appendix 3 - Structural variables, kurtosis and correlations.

Link: Sabatini_1160@supp1003.pdf

Appendix 4 - Distribution of estimated ages across forest types in Cilento National Park. Link: Sabatini_1160@supp1004.pdf

Appendix 5 - Statistical distribution of the SHI.

Link: Sabatini_1160@supp1005.pdf 